\title{
Multiple Sclerosis in Newfoundland and Labrador - A Model for Disease Prevalence
}

\author{
J.S. Sloka, W.E.M. Pryse-Phillips, M. Stefanelli
}

\begin{abstract}
Background: Newfoundland and Labrador, Canada, have been almost exclusively populated by immigrants from southwest England and southeast Ireland. The province's population grew largely by natural increase from 20,000 people in 1835 to half a million at present. Very little interregional migration occurred within the province. This uniquely-populated region and its subsequent founder effect provide the basis to develop models of disease prevalence. Objectives: To develop a model for the regional prevalence of multiple sclerosis (MS), accounting for settlement patterns and geographic location (latitude). Methods: All living MS patients with confirmed addresses (438 patients) in the province were mailed a survey requesting their place of birth. Regional prevalences were calculated from a $75 \%$ rate of return of the survey. Theoretical regional prevalences were proportionally calculated from the source prevalences of southwest England, southeast Ireland, Scotland and the Channel Islands based on settlement patterns. These theoretical regional prevalences were corrected for geographical variations of latitude based on observations in the United Kingdom. Theoretical and actual regional prevalences were compared. Results: When actual regional prevalences were compared with theoretical prevalences, very little variation was noted, especially after correcting for variation in latitude. Conclusion: A regional variation in MS prevalence is noted in the island portion of Newfoundland and Labrador. This regional variation can be modeled by using both migration patterns and latitudinal position. This model demonstrates that the prevalence of MS is influenced by both genetic and environmental contributions.
\end{abstract}

RÉSUMÉ: La sclérose en plaques à Terre-Neuve et au Labrador - un modèle de la prévalence de la maladie. Terre-Neuve et le Labrador au Canada, ont été peuplés presque exclusivement par des immigrants du sud-ouest de l'Angleterre et du sud-est de l'Irlande. La population de la province s'est accrue principalement par la croissance naturelle, de 20,000 habitants en 1835 à un demi-million actuellement, avec peu de migrations interrégionales à l'intérieur de la province. Cette région qui a des caractéristiques de peuplement particulières et un effet fondateur, sert de base à l'élaboration de modèles de prévalence de la maladie. Objectifs: Développer un modèle de la prévalence régionale de la sclérose en plaques (SEP) en tenant compte du mode de peuplement et de la localisation géographique (latitude). Méthodes: On a procédé à une enquête postale auprès de tous les patients vivants atteints de SEP et ayant une adresse de résidence confirmée dans la province (438 patients) leur demandant leur lieu de naissance. Le taux de réponse a été de $75 \%$. Le calcul des prévalences régionales est basé sur cette enquête. Des prévalences régionales théoriques ont été calculées proportionnellement aux taux de prévalence des régions sources, soit le sud-ouest de l'Angleterre, le sud-est de l'Irlande, l'Écosse et les Iles Anglo-Normandes, selon le mode de peuplement. Ces prévalences régionales théoriques ont été corrigées pour les variations géographiques de latitude basées sur les observations au Royaume-Uni. Les prévalences régionales théoriques et réelles ont été comparées. Résultats: On a relevé peu de variation dans les prévalences régionales réelles par rapport aux prévalences théoriques, surtout après correction pour la latitude. Conclusion: Nous avons observé une variation régionale dans la prévalence de la SEP dans la portion insulaire de Terre-Neuve et du Labrador. Cette variation régionale peut être modélisée en utilisant le profil migratoire et la latitude. Ce modèle démontre que la génétique et l'environnement influencent la prévalence de la SEP.

Can. J. Neurol. Sci. 2005; 32:43-49

Multiple sclerosis (MS) is a chronic disease of the central nervous system. It damages oligodendroglia and axons and may cause paralysis, sensory disturbances, incoordination, visual impairment, and alterations in bowel, bladder, and sexual function. ${ }^{1}$ The precise etiology of MS has not been elucidated;
From the Faculty of Medicine (Neurology), Memorial University of Newfoundland, (JSS); Faculty of Medicine (Neurology), Health Sciences Center (WEMP-P, MS); St. John's, NL, Canada

ReCEIVED MAy 31, 2004. AcCePtedinfinalForm OCtober 7, 2004. Reprint requests to: J. Scott Sloka, Faculty of Medicine (Neurology), Memorial University of Newfoundland, 108 Moss Heather Dr., St. John's, NL, Canada A1B 4S1. E-mail: p97jss@mun.ca 
however, many observations suggest that both genetic susceptibility and environmental factors are contributory. ${ }^{2}$

An incidence and prevalence study for the Canadian province of Newfoundland and Labrador has recently been completed demonstrating a population prevalence for MS of 94.4 per 100,000. This prevalence has been determined in the context of an unique social history and geography. ${ }^{3}$ The province was largely populated from two localities and population expansion was largely driven by natural increase since 1840. This extraordinary population process and subsequent founder effect has led to genetic discoveries for Mendelian disorders such as spastic ataxia, ${ }^{4}$ hereditary sensory and autonomic neuropathy type II, ${ }^{5}$ multiple endocrine neoplasia type $1,{ }^{6}$ hemophilia $\mathrm{A}^{7}$ and Bardet-Biedl syndrome ${ }^{8}$ as well as a gene that confers susceptibility to psoriatic arthritis. ${ }^{9}$ Indeed, the rates of certain genetic disorders have been shown to have a significantly higher incidence in this population when compared to other populations. ${ }^{10}$ It is for these and other reasons that Newfoundland and Labrador has become an excellent place to conduct genetic research. ${ }^{11}$

Seasonal colonies in Newfoundland were first established in 1610 with permanent settlements established throughout the 1700 s. Settlements ("outports") were initially seasonal, then temporary (overwintering for a year or two), and eventually permanent arrangements. The development of such permanent arrangements was prompted at least in part by the marriage of English and Irish male fishermen to female settlers. ${ }^{3}$ Expansion of settlements was driven by the increase in demand for cod in Europe and occurred due to natural increase after 1835. ${ }^{3,12}$ The high rate of natural increase deterred immigration because the districts themselves could hardly maintain their own growth pattern due to a limit in the rate of infrastructure growth.,12 The 1836 census showed that the original permanent population consisted of approximately 48\% English, 48\% Irish, 2\% Scottish, 1\% Channel Islands (Jersey and Guernsey) and 1\% other origins. ${ }^{3}$ Most of the Irish population migrated from the southeast of Ireland while most of the English population migrated from the central-southwest of England (Figure 1).

Once permanent settlements were established, intraprovincial migration (between districts) remained very low. One recent study showed that in two island outports, parents in only $7-9 \%$ of an east coast outport and parents in only $0.03 \%$ of a west coast outport came from outside the study area. ${ }^{13}$ This confirmed persistent population homogeneity in these outports and may be indicative of the situation in many outports on the island portion of the province. Additionally, another study compared allele frequencies of 12 red cell antigens from 10 outports with parental populations from England and Ireland and demonstrated persistent genetic isolation in selected outports. ${ }^{14}$

Along with low intra-provincial migration rates, English and Irish settlers were largely (genetically) separated from each other because of the low rate of intermarriage due to religious affiliations. For the most part, English settlers married other Protestants and the Irish married other Catholics. ${ }^{3}$ Only one in ten marriages was an interfaith union. ${ }^{3}$ This has also been confirmed by genetic analysis of allele frequencies demonstrating the persistence of separation of extraction based on faith. ${ }^{14}$

Due to the above unique social circumstances, $98 \%$ of the present population is of English or Irish descent. ${ }^{15}$ The population is almost evenly divided between the two countries of origin, and it has an initial founder population of a maximum of 20,000 with growth to 521,986 over 170 years. ${ }^{3}$ It is under these remarkable conditions that we have constructed a model for the prevalence of MS in Newfoundland. This study takes information regarding migration patterns, geographical location, and results from our own epidemiological study and constructs a model for the epidemiology of MS in Newfoundland and Labrador, accounting for both country of origin and for latitude.

\section{Methods}

The Canadian province of Newfoundland and Labrador comprises the island of Newfoundland and the mainland part of Labrador. The island portion of the province lies between latitude $46^{\circ}$ and $52^{\circ} \mathrm{N}$ and longitudes $52^{\circ}$ and $59^{\circ} \mathrm{W}$. Presently, nine practicing neurologists receive roughly 15,300 patient visits covering all illnesses yearly for a population of 521,986 (year 2001). Additionally, two authors (WP-P and MS) have, in turn, conducted a weekly clinic dedicated specifically to MS patients. All physician billing for the province is coordinated through the Medical Care Plan provincial health insurance system.

An incidence and prevalence study of MS was conducted for 2001 and a database was created with patient information for 493 confirmed cases. In October 2003, a survey was mailed to the living diagnosed patients from December 31, 2001 whose current addresses could be confirmed, with a subsequent mailer to those that did not initially respond after six weeks. The survey asked questions relating to place of birth and relatives with a diagnosis of MS.

Historically, migration and census data has been reported in terms of the bays within which the population settled into outports. Current population data was taken from the 2001 census and recalculated to represent this bay organization rather than the current federal census divisions. Migration information was available for Notre Dame Bay, Bonavista Bay, Trinity Bay, Conception Bay, St John's (including the Southern Shore), Placentia Bay, and the South Coast (including Fortune Bay).

\section{Prevalence of MS in England}

It is preferable to compare prevalences between studies that use similar diagnostic criteria (e.g. Allison and Millar ${ }^{16}$ vs Poser et $\mathrm{al}^{17}$ ) and most recent studies from the United Kingdom use the Poser criteria as was used in the first Newfoundland and Labrador study. As well, it is important to compare prevalence studies with the correct disease classification (clinically definite

\section{Table 1: Recent MS prevalence in several counties in southwest England}

\begin{tabular}{|c|c|c|c|}
\hline English Counties & SPR $(95 \%$ CI $)$ & Prevalence & Population \\
\hline Guernsey $^{40}$ & $120.2(96.0-144.3)$ & 113 & 61624 \\
\hline Jersey ${ }^{40}$ & $95.6(69.9-121.3)$ & 86.7 & 84082 \\
\hline \multicolumn{4}{|l|}{ Southampton and South } \\
\hline West Hampshire ${ }^{41}$ & 115 (104-127) & 99 & 417000 \\
\hline
\end{tabular}




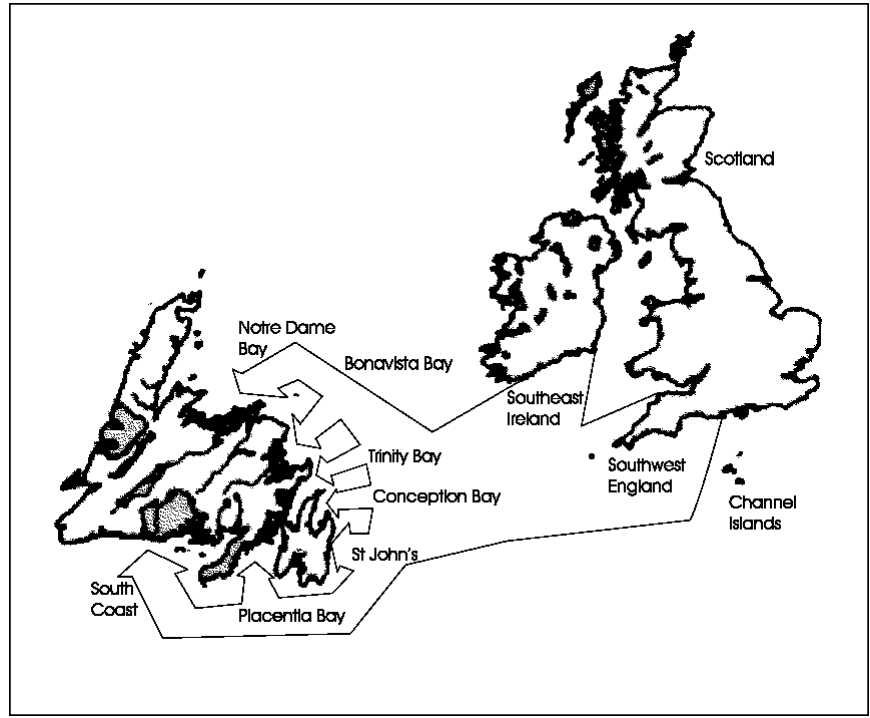

Figure 1: Map of migration patterns from southeast Ireland, southwest England, Scotland and the Channel Islands to the island of Newfoundland with its various bays.

plus probable vs all cases). ${ }^{17}$ For comparison reasons, standardized prevalence ratios (SPRs) are used when prevalence figures from the United Kingdom are quoted and are based on the 1961 Northern Ireland population ${ }^{18}$ as per the current convention.

The prevalence of MS in England is well-studied. ${ }^{18,19}$ Recent epidemiological studies confirm the high overall prevalence of MS in the United Kingdom with SPRs of 116/100,000 in England and Wales and 158/100,000 in Scotland. ${ }^{18}$ Since most migration to Newfoundland from England was from the Devon and Wessex counties of the southwest of England, prevalence studies from these areas were searched for using Medline for the most recent 15 years using the search terms ("United Kingdom", "UK", "Britain", "England", "Ireland", "Scotland" or "Wales"), "multiple sclerosis" and "prevalence". The references from published articles were also searched and the results of the searches are shown in Table 1. Only studies that used Poser criteria (clinically definite and probable MS) and stated SPRs with respect to 1961 Northern Ireland were included.

\section{Prevalence of MS in Ireland}

Only one recent study was found that stated the prevalence of MS in any part of Ireland, demonstrating a prevalence in Wexford (southeast Ireland) of 120.7/100,000 and a prevalence in Donegal (northwest Ireland) of $184.6 / 100,000 .{ }^{20}$ With the author's permission, these prevalences were recalculated to an SPR of 118.8/100,000 for Wexford using the Northern Ireland population of 1961 as the reference. The recalculated SPR for Donegal is $189.8 / 100,000$.

\section{Migration from Southwest England and Southeast Ireland to Newfoundland}

Most migration from England occurred from the southwest counties of Devon, Dorset, and Somerset and from Hampshire ${ }^{3}$ (Table 2). Taking an average of SPRs from all available studies in these southwest counties, weighted by population, an average SPR of $115 / 100,000$ is calculated. The estimated SPR for England is $116 / 100,000 .^{18}$

Eighty five percent of migration from Ireland occurred from the four counties of Kilkenny, Wexford, Waterford and Tipperary. ${ }^{3}$ Prevalence data were available for Wexford county and were used as a representative prevalence for the southeast of Ireland since all four aforementioned counties are geographically connected. Prevalences for the rest of Ireland may lie somewhere between that of Donegal in the north and Wexford in the south since it has been demonstrated that a north-south prevalence gradient occurs in the United Kingdom. ${ }^{18,20}$ (Similarly, a southnorth prevalence gradient occurs in Australia $\left.{ }^{21}\right)$. A weighted average of $85 \%$ of the Wexford prevalence and $15 \%$ of the Ireland estimate ${ }^{3}$ gives an estimated SPR contribution from Ireland of 129.4/100,000.

The Channel Island SPR is a weighted average based on prevalences from Guernsey and Jersey and is 106/100,000. The SPR for Scotland is $158 / 100,000 .^{18}$

Information about exact migration patterns from Ireland to various areas of Newfoundland is not available. However, the 1835 census data combined with estimates by Mannion and

Table 2: Migration statistics for Newfoundland prior to 1836

\begin{tabular}{|c|c|c|c|c|c|c|c|c|c|}
\hline & $\begin{array}{l}\text { Notre } \\
\text { Dame Bay }\end{array}$ & $\begin{array}{l}\text { Bonavista } \\
\text { Bay }\end{array}$ & $\begin{array}{l}\text { Trinity } \\
\text { Bay }\end{array}$ & $\begin{array}{l}\text { Conception } \\
\text { Bay }\end{array}$ & St John's & $\begin{array}{l}\text { Southern } \\
\text { Shore }\end{array}$ & $\begin{array}{l}\text { Placentia } \\
\text { Bay }\end{array}$ & $\begin{array}{l}\text { South } \\
\text { Coast }\end{array}$ & Total \\
\hline Devon & $0 \%$ & $0 \%$ & $10 \%$ & $14 \%$ & $20 \%$ & $25 \%$ & $0 \%$ & $0 \%$ & $13 \%$ \\
\hline Wessex & $88 \%$ & $88 \%$ & $60 \%$ & $22 \%$ & $3 \%$ & $0 \%$ & $50 \%$ & $50 \%$ & $31 \%$ \\
\hline $\begin{array}{l}\text { Southwest England } \\
\text { (Devon and Wessex) }\end{array}$ & $88 \%$ & $88 \%$ & $70 \%$ & $36 \%$ & $23 \%$ & $25 \%$ & $50 \%$ & $50 \%$ & $44 \%$ \\
\hline Other English & $0 \%$ & $0 \%$ & $10 \%$ & $8 \%$ & $7 \%$ & $0 \%$ & $0 \%$ & $0 \%$ & $6 \%$ \\
\hline Channel Islands & $0 \%$ & $0 \%$ & $0 \%$ & $3 \%$ & $0 \%$ & $0 \%$ & $0 \%$ & $0 \%$ & $1 \%$ \\
\hline Scottish & $0 \%$ & $0 \%$ & $0 \%$ & $3 \%$ & $3 \%$ & $0 \%$ & $0 \%$ & $0 \%$ & $2 \%$ \\
\hline Irish & $12 \%$ & $12 \%$ & $20 \%$ & $50 \%$ & $67 \%$ & $75 \%$ & $50 \%$ & $50 \%$ & $47 \%$ \\
\hline
\end{tabular}

\footnotetext{
*These migration statistics are derived from tables in Mannion, ${ }^{3}$ from Plate 7 of the Atlas of Newfoundland and Labrador, and from personal discussions with Dr Mannion and Dr Handcock regarding migration patterns in Newfoundland and Labrador. They are largely derived from statistical information gathered from the 1836 census.
} 


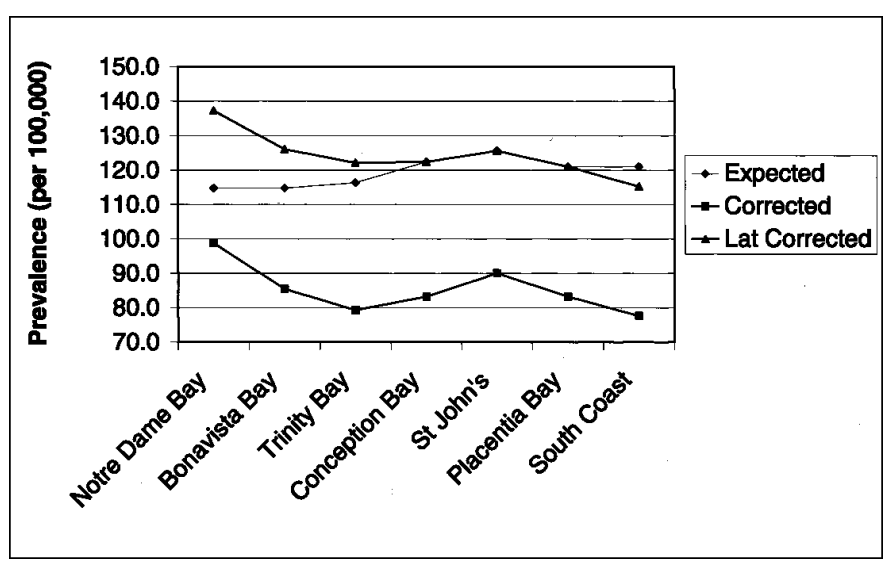

Figure 2: This figure plots the expected, corrected, and latitudinally corrected SPRs from Table 3. Visually similar trends are noted between the corrected SPR from the survey and the latitudinally corrected model of expected $S P R$.

Handcock ${ }^{3}$ can be used to estimate the migration patterns to the various regions (bays) in Newfoundland. These estimates are depicted in Table 2 and are based on the mercantile trade patterns of the cod fishery during the period of immigration before $1836 .^{12}$

\section{RESULTS}

\section{Provincial Prevalence}

As per the current prevalence study, 491 patients were alive on December 31, 2001, giving a population prevalence of 95.7 per 100,000. The SPR for Newfoundland and Labrador based on the 1961 Northern Ireland population was calculated to be 78.4/100,000 (95\% CI:70.7-88.0). This difference between the absolute prevalence and the SPR is due to the relatively older

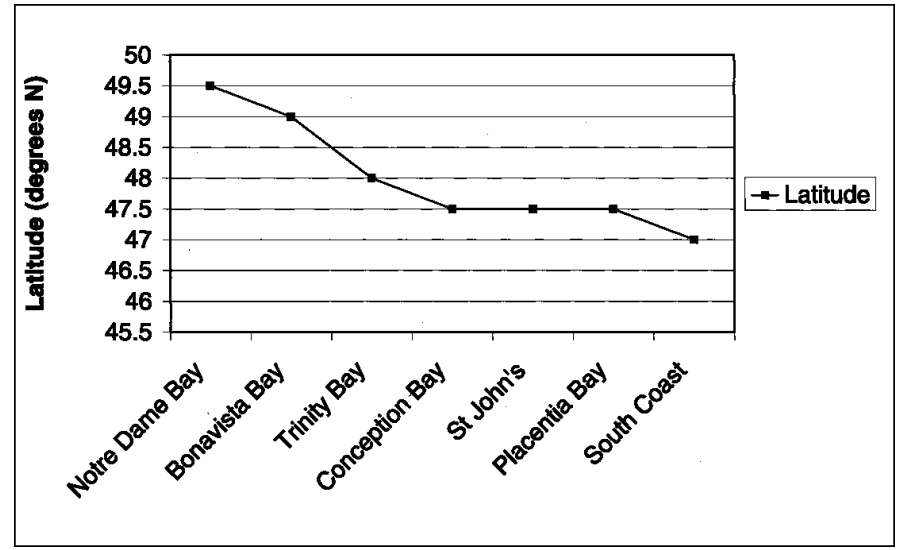

Figure 3: Approximations of average latitude for the Bays of Newfoundland.

population of Newfoundland and Labrador compared to 1961 Northern Ireland. Table 3 shows the calculated expected SPR based on the contribution of migration from each region of origin and is $121.6 / 100,000$ (95\% CI: 112.0-131.1). This is significantly different than the SPR of $78.4 / 100,000$ found in our current prevalence study $(\mathrm{z}=3.96, \mathrm{p}<0.0001)$. This difference may be either due to the fact that the genetics of the immigrant population do not reflect the actual prevalence seen in the destination country, or to some environmental effect also contributing to the actual prevalence. Since regional migration patterns were available, the regional birth prevalence of MS was analysed to look for patterns of prevalence that may reflect historical migration patterns.

\section{Table 3: Aggregate weighted contribution of prevalence from each area of migration to Newfoundland and Labrador}

\begin{tabular}{|c|c|c|c|c|c|c|c|c|}
\hline \multicolumn{9}{|c|}{ Expected SPRs Based on Migration Patterns } \\
\hline & $\begin{array}{l}\text { Notre Dame } \\
\text { Bay }\end{array}$ & $\begin{array}{l}\text { Bonavista } \\
\text { Bay }\end{array}$ & $\begin{array}{l}\text { Trinity } \\
\text { Bay }\end{array}$ & $\begin{array}{l}\text { Conception } \\
\text { Bay }\end{array}$ & St John's & $\begin{array}{l}\text { Placentia } \\
\text { Bay }\end{array}$ & $\begin{array}{l}\text { South } \\
\text { Coast }\end{array}$ & Total \\
\hline Southwest England & 98.6 & 98.6 & 78.9 & 40.7 & 26.3 & 56.4 & 56.4 & 49.6 \\
\hline Other English & 0 & 0 & 11.6 & 9.7 & 7.7 & 0 & 0 & 7.0 \\
\hline Channel Islands & 0 & 0 & 0 & 2.9 & 0 & 0 & 0 & 1.1 \\
\hline Scottish & 0 & 0 & 0 & 4.4 & 5.3 & 0 & 0 & 3.2 \\
\hline Irish & 16.2 & 16.2 & 25.9 & 64.7 & 86.6 & 64.7 & 64.7 & 60.8 \\
\hline Expected SPR & 114.8 & 114.8 & 116.4 & 122.4 & 125.6 & 121.1 & 121.1 & 121.6 \\
\hline \multicolumn{9}{|c|}{ Survey Results } \\
\hline Population & 51791 & 25383 & 27346 & 72630 & 134299 & 24193 & 27942 & \\
\hline MS Number & 33 & 14 & 14 & 39 & 78 & 13 & 14 & \\
\hline MS Prevalence & 63.7 & 55.2 & 51.2 & 53.7 & 58.1 & 53.7 & 50.1 & \\
\hline Corrected SPR & 98.7 & 85.4 & 79.3 & 83.2 & 90.0 & 83.2 & 77.6 & \\
\hline
\end{tabular}

*Percentages of contribution were derived in Table 2 above, SPRs were derived above, and the total expected SPR is calculated as a weighted contribution. The survey results are also shown in the bottom part of the table. The MS number is the number of people who stated they were born in a specific region. The prevalence is calculated via the MS number and the population. The corrected SPR is corrected for population and also for survey results - since the return rate was $75 \%$, the SPR was scaled up to reflect the deficit caused by the nonperfect (although substantial) return rate. 


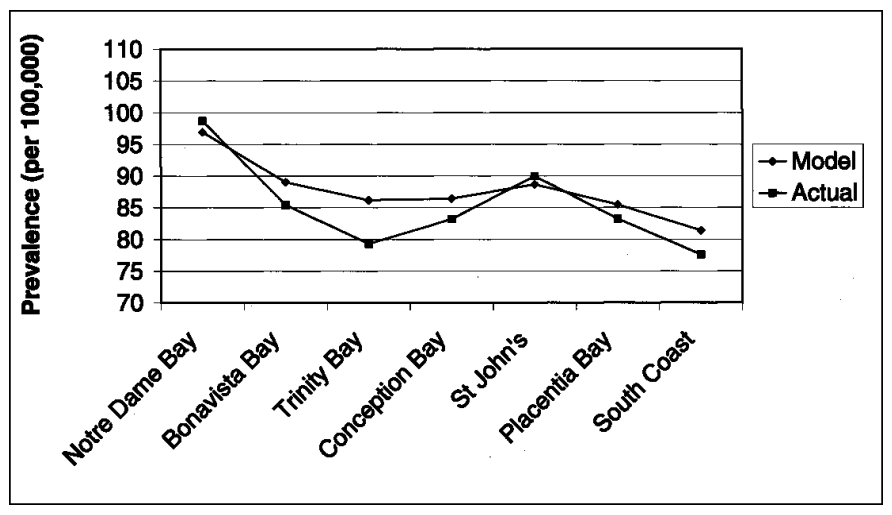

Figure 4: This figure plots the latitudinally corrected SPRs from the model along with the actual prevalence measured in each region (corrected for age and for survey response).

\section{Survey Results}

In October 2003, 438 patient addresses were confirmed for the patients that were known to be still alive and these patients were mailed surveys. After two survey mailings, 328 surveys were returned (a $75 \%$ rate of return). There were no differences between the patients that returned the survey and all the patients in the database in terms of average age ( 45.7 years vs 45.2 years: $\mathrm{p}=0.53)$, female to male ratio $(2.72: 1$ vs $2.86: 1: \mathrm{p}=0.76)$, age of first symptoms (32.2 years vs 32.4 years: $\mathrm{p}=0.81$ ) and proportion of those patients with relapsing remitting MS (83\% vs $83 \%$ : $\mathrm{p}=0.97$ ), respectively. These survey results, based on derived census divisions according to bays, are shown in the bottom part of Table 3.

\section{Comparison of Model Results with Actual Results}

The expected SPR and corrected SPR from Table 3 are plotted in Figure 2 for visual comparison. Intriguingly, one can see the trend of expected SPR based on region reflect the actual SPR trend based on region.

The SPRs for Notre Dame Bay and Bonavista Bay are much higher than the SPRs in more southern bays. This could be explained by the effect of latitude ${ }^{21}$ also noted in England ${ }^{18}$ and Ireland. ${ }^{20}$ Since most regions are located at a similar latitude (except for Bonavista Bay and Notre Dame Bay), possibly a latitudinal effect ${ }^{21}$ may account for the increased actual prevalence compared to an expected prevalence that is based solely on migration patterns. Therefore, an attempt was made to refine the model based on latitudinal variation in addition to migration patterns.

Most regions are between latitudes $47-48^{\circ} \mathrm{N}$ while the population in Bonavista Bay is centered at approximately $49^{\circ} \mathrm{N}$ and the population in Notre Dame Bay is centered at approximately $49.5-50^{\circ} \mathrm{N}$. Since the prevalence of MS increases with increasing latitude, if the latitudinal effect on MS prevalence is also modelled, the expected SPRs for both Bonavista Bay and Notre Dame Bay would be higher, with the correction for Notre Dame Bay being larger than for Bonavista Bay.

Figure 3 shows approximations of the average latitudes of the bays of Newfoundland. By using recent prevalence studies in the United Kingdom and the idea that a prevalence gradient exists, a correction factor might be estimated for a latitudinal gradient in Newfoundland. The UK county of Southampton, situated at latitude $50^{\circ} 55^{\prime}$, has an SPR of 115/100,000 while Fife county in Scotland is situated at latitude $56^{\circ} 12^{\prime}$ and has an SPR of $178 / 100,000$. If the latitudes for these two counties are used to derive a linear SPR correction factor based on latitude, a correction factor of $9.8 \%$ per degree increase in latitude is calculated. The corrected SPR for Bonavista Bay and Notre Dame Bay is plotted in Figure 2 using this correction factor with St John's as a reference location at $47.5^{\circ}$ and this corrected curve more closely reflects the SPR pattern seen in the actual survey data.

The model of disease prevalence corrected for local variations in latitude as displayed in Figure 2 demonstrates a visually similar curve to the actual disease prevalence from the survey (corrected for survey response). Further refinements to the model can be made by correcting for the difference in latitude between the UK to Newfoundland. Since St John's, Newfoundland (the reference point for localized latitudinal correction) is approximately $3^{\circ}$ south of Southampton, a correction factor of $3 \times 9.8 \%$ per degree can be applied to all points to the model and is displayed in Figure 4. The model curve shows remarkable similarity to the corrected prevalence from the survey.

\section{First Degree Relatives}

The survey also asked questions regarding first degree relatives. These results are listed in Table 4 . The incidence and prevalence study demonstrated a female to male ratio of 2.69:1. Table 4 suggests that there is a higher correlation to female relatives in the MS population than the overall female to male ratio. The number of first degree female relatives is 29 and males is 8 , a ratio of $3.63: 1$. This difference is nonsignificant at $(\mathrm{z}=0.725, \mathrm{p}=0.46)$. This was important to note because of the different migration processes for females versus males. As noted above, the indigent females were more likely to marry seasonal males than indigent males were likely to marry seasonal females. Therefore, permanent female settlers were more likely to be born in Newfoundland via natural increase than males during the period of initial migration. ${ }^{3}$ No difference between the gender ratio of MS patients versus relatives of MS patients with MS was noted, although a type II error is possible due to the small number of relatives with MS from the survey results.

Table 4: First degree relatives of MS patients from survey returns

\begin{tabular}{lc}
\hline First Degree Relative & Number \\
Sisters & 21 \\
Brothers & 3 \\
Mothers & 4 \\
Fathers & 4 \\
Daughters & 4 \\
Sons & 1
\end{tabular}




\section{DISCUSSION}

Evidence of a genetic contribution to the etiology of MS arises from several sources of observations. Concordance rates among monozygotic twins with MS is approximately $31-40 \%$ whereas those among fraternal and nontwin siblings is approximately $3-5 \% .^{23,24}$ This demonstrates an approximate six to eight times increase in relative risk. As well, prevalence rates among nonbiological siblings adopted into a family are similar to prevalence rates of MS found in the general population and are significantly less than for biological relatives, suggesting a significant genetic component to the familial aggregation of MS. Genetic susceptibility has also been shown to vary with several genetic markers, ${ }^{25-27}$ especially the human leukocyte antigen DR2 antigen on chromosome 6. The mode of transmission of genetic susceptibility is complex and sporadic in most cases. ${ }^{2}$

Even though there is an increased susceptibility to MS for monozygotic twins, most monozygotic twins are discordant even after correction for age and magnetic resonance findings. ${ }^{24}$ Areas at increased risk of MS still only have rates of 100-150 per 100,000 and so a six to eight times increase in relative risk is still only an absolute risk of $1 / 100$ population. Therefore, an environmental contribution to etiology also appears likely.

Evidence for such an environmental contribution comes from various sources. The increased MS prevalence with higher latitudes is one such source ${ }^{28}$ but against this correlation with latitude, large variations in prevalence among geographically close regions with similar latitudes have been noted in places such as Sicily and Malta. ${ }^{29,30}$ This may suggest that locallyspecific etiologies (either environmental or genetic) also contribute to disease pathogenesis.

Migrant studies also suggest an environmental component. The results of multiple migrant studies in $\mathrm{MS}^{31-37}$ suggest that people who migrate before adolescence acquire the incidence rates of the region to which they have migrated. In contrast, people that migrate to a region after adolescence retain the incidence rate of the region from which they grew up. ${ }^{38}$ This compelling evidence is fairly consistent for migration from areas of high risk to areas of low risk and suggests that there is a part of the disease process that depends on geographical location, possibly involving an environmental pathogen. However, the evidence is also fairly consistent that migration from areas of low risk to areas of high risk is not associated with a substantial change in risk. ${ }^{38}$ This diminishes the strength of conclusions that can be drawn from all migrant studies but does permit the observation that both geography and age play some as-yet undetermined role in the natural history of the disease.

This study has shown how the expected prevalence of a region may be calculated from knowledge of the geographical origins of its population. The results suggest that the actual trend among regions is similar to the expected trend given the migration patterns with a correction factor added for the larger changes in latitude. Indeed, there seems to be both genetic and environmental processes involved in the etiology of MS in Newfoundland and Labrador.

Many assumptions were made in constructing this model. It was assumed that immigration after 1836 was insignificant, which by all accounts it was. It is also assumed that the populations of present-day Ireland, England and Scotland are similar to the populations that became the source of migration to
Newfoundland and Labrador before 1836. It may be that these populations were not as genetically stable as the geneticallyisolated populations of Newfoundland's bays were. Moreover, the model assumes that general prevalences from one or several counties can be extrapolated to an entire region (e.g. all of southeast Ireland from Wexford) and that general prevalences for an entire country can be linearly calculated based on weighted averages of prevalences from regions across the country. This seems to have held true so far for the United Kingdom in terms of a general estimate, ${ }^{18}$ and it has been suggested for Ireland as well. $^{20}$

The model also assumes that the prevalence of MS varies linearly with latitude (as a first order approximation). This has not yet been demonstrated formally and is a major assumption. The trend could, in fact, be a complex, nonlinear relation, such as Rothwell has suggested for the south of Scotland. ${ }^{39}$ However, the assumption does not detract from a general statement that regions at higher latitude have an increased prevalence even (and especially) given a similar population. This has been demonstrated by the migrant studies explained above.

The original incidence and prevalence study ${ }^{22}$ noted a relative increase in the prevalence of cases in the region closest to the capital city that was most likely due to reporting bias. We believe that our case ascertainment is near complete in this current study because the current study used several search methodologies including previous databases, province-wide billing information and case searches through most practicing neurologists in the province. This should have greatly reduced any reporting bias in our model. As well, an increased number and more uniform distribution of practicing neurologists over the time period of the current study should also have reduced the reporting bias.

This study has taken MS prevalence data from regions of origin and has proportionally applied these rates to the destinations of immigration for the island portion of the province of Newfoundland and Labrador, Canada. This was made possible because of the unique social geography of the province. A model for regional prevalences has been suggested based both on migration patterns and latitudinal variation. Although the overall prevalence differs from the model's expected value, the regionalized prevalence trend is similar. This supports the idea that the etiology of MS is influenced by both genetic and environmental factors.

\section{ACKNOWLEDGEMENTS}

The authors thank Gwen Alcock, RN, of the NL MS Clinic, Don MacDonald from the Newfoundland and Labrador Center for Health Information, Dr Blair Fleming and Coleen Owens from the NLMedical Care Plan, Dr Sharon Buehler and Dr V Gadag of the Division of Community Health, MUN, and the NL neurologists, both current and previously-practicing.

\section{REFERENCES}

1. Paty DW, Ebers GC. Multiple Sclerosis. Contemporary Neurology Series 1998; 50:48-138.

2. Noseworthy JH, Lucchinetti C, Rodriguez M, Weinshenker BG. Multiple sclerosis. N Engl J Med 2000; 343(13):938-952.

3. The Peopling of Newfoundland : essays in historical geography. St John's: Memorial University of Newfoundland, 1977.

4. Meijer IA, Hand CK, Grewal KK, et al. A locus for autosomal dominant hereditary spastic ataxia, SAX1, maps to chromosome 12p13. Am J Hum Genet 2002; 70(3):763-769. 
5. Lafreniere RG, MacDonald ML, Dube MP, et al. Identification of a novel gene (HSN2) causing hereditary sensory and autonomic neuropathy type II through the study of Canadian genetic isolates. Am J Hum Genet 2004; 74(5):1064-1073.

6. Olufemi SE, Green JS, Manickam P, et al. Common ancestral mutation in the MEN1 gene is likely responsible for the prolactinoma variant of MEN1 (MEN1Burin) in four kindreds from Newfoundland. Hum Mutat 1998; 11(4):264-269.

7. Xie YG, Zheng H, Leggo J, Scully MF, Lillicrap D. A founder factor VIII mutation, valine 2016 to alanine, in a population with an extraordinarily high prevalence of mild hemophilia A. Thromb Haemost 2002; 87(1):178-179.

8. Young TL, Penney L, Woods MO, et al. A fifth locus for BardetBiedl syndrome maps to chromosome 2q31. Am J Hum Genet 1999; 64(3):900-904.

9. Rahman P, Bartlett S, Siannis F, et al. CARD15: a pleiotropic autoimmune gene that confers susceptibility to psoriatic arthritis. Am J Hum Genet 2003; 73(3):677-681.

10. Green JS, Parfrey PS, Harnett JD, et al. The cardinal manifestations of Bardet-Biedl syndrome, a form of Laurence-Moon-Biedl syndrome. N Engl J Med 1989; 321(15):1002-1009.

11. Rahman P, Jones A, Curtis J, et al. The Newfoundland population: a unique resource for genetic investigation of complex diseases. Hum Mol Genet 2003; 12 Spec No 2:R167-R172.

12. Staveley M. Migration and Mobility in Newfoundland and Labrador: A Study in Population Geography. Memorial University of Newfoundland, 1973.

13. Bear JC, Nemec TF, Kennedy JC, et al. Persistent genetic isolation in outport Newfoundland. Am J Med Genet 1987; 27(4):807-830.

14. Martin LJ, Crawford MH, Koertvelyessy T, et al. The population structure of ten Newfoundland outports. Hum Biol 2000; 72(6):997-1016.

15. Statistics Canada. 2001 Census. 2004.

16. Allison RS, Millar JHD. Prevalence and familial incidence of disseminated sclerosis. Ulster Med J 1954;(Supp 2):92.

17. Poser CM, Paty DW, Scheinberg L, et al. New diagnostic criteria for multiple sclerosis: guidelines for research protocols. Ann Neurol 1983; 13(3):227-231.

18. Robertson N, Compston A. Surveying multiple sclerosis in the United Kingdom. J Neurol Neurosurg Psychiatry 1995; 58(1):2-6.

19. Millar JHD. Multiple sclerosis in Northern Ireland. In: Clifford Rose F, (Ed). Clinical Neuroepidemiology. Tunbridge Wells: Pitman Medical, 1980: 222-227.

20. McGuigan C, McCarthy A, Quigley C, et al. Latitudinal variation in the prevalence of multiple sclerosis in Ireland, an effect of genetic diversity. J Neurol Neurosurg Psychiatry 2004; 75(4):572-576

21. McLeod JG, Hammond SR, Hallpike JF. Epidemiology of multiple sclerosis in Australia. With NSW and SA survey results. Med J Aust 1994; 160(3):117-122.

22. Pryse-Phillips WE. The incidence and prevalence of multiple sclerosis in Newfoundland and Labrador, 1960-1984. Ann Neurol 1986; 20(3):323-328.
23. Ebers GC, Sadovnick AD, Risch NJ. A genetic basis for familial aggregation in multiple sclerosis. Canadian Collaborative Study Group. Nature 1995; 377(6545):150-151.

24. Sadovnick AD, Armstrong H, Rice GP, et al. A population-based study of multiple sclerosis in twins: update. Ann Neurol 1993; 33(3):281-285.

25. Schrijver HM, Crusius JB, Uitdehaag BM, et al. Association of interleukin-1beta and interleukin-1 receptor antagonist genes with disease severity in MS. Neurology 1999; 52(3):595-599.

26. Myhr KM, Raknes G, Nyland H, Vedeler C. Immunoglobulin G Fcreceptor (FcgammaR) IIA and IIIB polymorphisms related to disability in MS. Neurology 1999; 52(9):1771-1776.

27. Evangelou N, Jackson M, Beeson D, Palace J. Association of the APOE epsilon4 allele with disease activity in multiple sclerosis. J Neurol Neurosurg Psychiatry 1999; 67(2):203-205.

28. Acheson ED. Epidemiology of multiple sclerosis. Br Med Bull 1977; 33(1):9-14.

29. Vassallo L, Elian M, Dean G. Multiple sclerosis in southern Europe. II: Prevalence in Malta in 1978. J Epidemiol Community Health 1979; 33(2):111-113.

30. Dean G, Grimaldi G, Kelly R, Karhausen L. Multiple sclerosis in southern Europe. I: Prevalence in Sicily in 1975. J Epidemiol Community Health 1979; 33(2):107-110.

31. Leibowitz U, Kahana E, Alter M. The changing frequency of multiple sclerosis in Israel. Arch Neurol 1973; 29(2):107-110.

32. Alter M, Kahana E, Loewenson R. Migration and risk of multiple sclerosis. Neurology 1978; 28(11):1089-1093.

33. Alter M, Okihiro M, Rowley W, Morris T. Multiple sclerosis among Caucasians and Orientals in Hawaii. Neurology 1970; 20(4):399.

34. Alter M, Leibowitz U, Speer J. Risk of multiple sclerosis related to age at immigration to Israel. Arch Neurol 1966; 15(3):234-237.

35. Dean G, Elian M. Age at immigration to England of Asian and Caribbean immigrants and the risk of developing multiple sclerosis. J Neurol Neurosurg Psychiatry 1997; 63(5):565-568.

36. Detels R, Visscher BR, Haile RW, et al. Multiple sclerosis and age at migration. Am J Epidemiol 1978; 108(5):386-393.

37. Hammond SR, English DR, McLeod JG. The age-range of risk of developing multiple sclerosis: evidence from a migrant population in Australia. Brain 2000; 123(Pt 5):968-974.

38. Gale CR, Martyn CN. Migrant studies in multiple sclerosis. Prog Neurobiol 1995; 47(4-5):425-448.

39. Rothwell PM, Charlton D. High incidence and prevalence of multiple sclerosis in south east Scotland: evidence of a genetic predisposition. J Neurol Neurosurg Psychiatry 1998; 64(6):730735.

40. Sharpe G, Price SE, Last A, Thompson RJ. Multiple sclerosis in island populations: prevalence in the Bailiwicks of Guernsey and Jersey. J Neurol Neurosurg Psychiatry 1995; 58(1):22-26.

41. Roberts MH, Martin JP, McLellan DL, McIntosh-Michaelis SA, Spackman AJ. The prevalence of multiple sclerosis in the Southampton and South West Hampshire Health Authority. J Neurol Neurosurg Psychiatry 1991; 54(1):55-59. 